\title{
The Use of Simulations for the Need of Environment Protection
}

\author{
Jiří Barta \\ University of Defence, Kounicova 65, 66210 Brno, Czech Republic \\ jiri.barta@unob.cz
}

\begin{abstract}
The environmental protection is currently a very hot topic. The article deals with the perspectives and possibilities for deployment of "new technologies" or already known technologies but in new ways in order to protect selected environment. In the first part, the paper is focused on education and technologies used in the educational process at the University of Defence, at the Department of Civil Protection. The second part outlines the possibilities of using this technology to protect specialized workplaces, which is also applicable to environmental protection.
\end{abstract}

Keywords: Simulator, Environment, Information Technology, Study Programme, Specialized Workplaces.

\section{Introduction}

We live in a time which can be characterized as a continuous development of technologies. These technologies should provide easy access to information, and especially to their most effective utilization. The computer support of management takes part in many different spheres of human activity. At present, there are many available systems and technologies, which enable the formulation of crisis plans, collaboration between the state and private subjects, monitoring of infrastructure and other necessary services for crisis managers in various organizations [3].

\section{Problem Formulation}

Information systems and technologies can be used in both public administration and the private sector. They can support successful solutions of crisis situations. One of the areas, where these technologies are used, is education.

Higher education institutions form the highest level of the Czech education. They offer accredited degree programmes at three levels: bachelor's, master's and doctoral degree programmes. Apart from public and private higher education institutions there are state institutions in the Czech Republic. The University of Defence is one of the state institutions, which is under the responsibility of the Ministry of Defence. 
There is not only an educational process but also research activities both in defence technology for the Army of the Czech Republic as well as in the field of information technology and crisis management system. The focus is on systems that support analyzing, planning and solving emergency and crisis situations. One of these research projects is dealing with interoperability specialized centers of crisis management. This project uses the outputs from modeling programs (see section 3.1) and implements these outputs to the process of crisis management and environmental protection.

\section{Education at the University of Defence}

This university educates and prepares military professionals and other experts. The scope of university work is defined with focuses of education, formation and training of these professionals as required by the Army of the Czech Republic and research projects in favour of the Ministry of Defence and Public Administrations [8].

The University of Defence is the university-type higher education institution, which offers all types of degree programmes (bachelor's, master's and doctoral) and carries out associated research, developmental and other creative activities.

\subsection{Professional and Educational Aspects}

The University of Defence consists of three faculties: the Faculty of Economics and Management, the Faculty of Military Technology and the Faculty of Military Health Sciences. The academic year 2001/2002 was the first year for the study module "Population Protection" that started at the Faculty of Economics and Management and which is guaranteed by the Department of Population Protection. This department focuses on the area of population protection, crisis management and civil and military cooperation. Furthermore, the department solves the problems connected with military and non-military emergencies. The department emphasizes issues associated with humanitarian aid, environmental security, major accident prevention, information systems and risk analysis.

The Department of Population Protection cooperates with many institutions, e. g. the Population Protection Institute, The Ministry of Interior of the Czech Republic, the Nuclear Research Institute Rez plc., the Transport Research Centre and other universities and institutions not only in the Czech Republic.

Students in both bachelor's and master's degree study programmes are informed about actual problems of population protection. They pass theoretical subjects (e.g. Economics, Computer Science, Mathematics, Law: Czech National Security and Defence), applied subjects (e.g. Economic-Mathematic Methods, Accounting, Enterprise Theory) and profile subjects (e.g. Crisis Management, Natural Disasters and Industrial Accidents, Population Protection, Environment Protection, Dangerous Substances, Classification and Modelling of Risks, Public Administration Information System etc.). The department is also aimed at doctoral degree study programme and guarantees the programme Forces and Civil Protection [8]. 


\subsection{Aims and Scientific Activities}

The main purpose of this programme is to prepare highly-qualified and specialized experts for basic and applied research, research workers, education and practice of civilian protection in accordance with requirements and needs of the NATO [5].

Scientific activity includes the following areas:

- crisis management in civil protection during non-military crisis situation,

- logistic support of non-military crisis situation, especially at the field of solution of material standards for civil protection at crisis situation and coordination of human aid with utilization of non-profit-making organizations,

- raising of environmental safety at the level of advanced armies of NATO,

- dangerous substances detection at industrial accidents and natural disasters,

- optimization of information and software support for prevention and solution of consequences of extraordinary events and for simulation of these processes,

- interoperability at the crisis management.

It is possible to say that information technologies are used almost in all scientific activities.

\section{Information Technologies Used at the Department of Civil Protection}

At the Department of Population Protection students have an opportunity to meet with the issue of information technologies in the subject "Information Systems of Crisis Management I and II". In this subject, they can get information not only about IT but also information, which support making up the information systems of public and state administrations.

The aim of this subject is to educate students for principal work with chosen information systems that are closely linked with crisis management. Students learn how to use computer programmes for modelling possible impacts and consequences of industrial accidents with the dangerous substances release.

Information systems are products made in order to support effective decision making of crisis managers. For the solution of the scheduled objectives, especially Geographical Information Systems are used [4]. The overview of the most important information systems that are intended for education at the Department of Population Protection is in the table 1.

Table 1. Information Systems at the Department of Population Protection [1, 2, 3, 5]

\begin{tabular}{|c|l|l|}
\hline \multicolumn{1}{|c|}{ Area } & \multicolumn{1}{|c|}{$\begin{array}{c}\text { Information } \\
\text { system }\end{array}$} & \multicolumn{1}{|c|}{ Description } \\
\hline $\begin{array}{l}\text { Civilian Emer- } \\
\text { gency Planning }\end{array}$ & ARGIS & $\begin{array}{l}\text { Information system for Planning of Civil } \\
\text { Resources, which is important for self- } \\
\text { solution of extraordinary events in the Czech } \\
\text { Republic }\end{array}$ \\
\hline
\end{tabular}


Table 1. (continued)

\begin{tabular}{|c|c|c|}
\hline \multirow[t]{2}{*}{ Monitoring } & MONIS & This system monitors critical infrastructure. \\
\hline & PREMIS & $\begin{array}{l}\text { This system, which is sponsored by the } \\
\text { department of informatics of the Prague } \\
\text { municipality, provides public information } \\
\text { about the quality of the air of Prague. These } \\
\text { systems were made especially for Czech } \\
\text { market and monitor not only air but also } \\
\text { road practicability, river level etc. }\end{array}$ \\
\hline \multirow[t]{3}{*}{ Modelling } & $\begin{array}{l}\text { TerEx } \\
\text { (Terrorist Expert) }\end{array}$ & $\begin{array}{l}\text { The tool for immediate forecast of explo- } \\
\text { sions and chemical release hazards. }\end{array}$ \\
\hline & WAVE & $\begin{array}{l}\text { Program for modelling of the dam destruc- } \\
\text { tion. }\end{array}$ \\
\hline & SYMOS'97 & $\begin{array}{l}\text { The tool for dispersion modelling of emis- } \\
\text { sions from sources of pollution [2]. }\end{array}$ \\
\hline Planning & $\begin{array}{l}\text { EMOFF } \\
\text { (Emergency Of- } \\
\text { fice) }\end{array}$ & $\begin{array}{l}\text { It is technology to help in emergency plan- } \\
\text { ning and management and business continu- } \\
\text { ity. The system integrates software tool for } \\
\text { analysis, planning and emergency situation } \\
\text { support. }\end{array}$ \\
\hline $\begin{array}{l}\text { Simulation of } \\
\text { Emergency } \\
\text { Event }\end{array}$ & $\begin{array}{l}\text { ESIM } \\
\text { (Emergency } \\
\text { Management } \\
\text { Simulator) }\end{array}$ & $\begin{array}{l}\text { Simulator for Crisis Management Training } \\
\text { and Exercising. It is made for obtaining of } \\
\text { skilled staff and preparedness to deal with } \\
\text { various situations. }\end{array}$ \\
\hline Analysis & $\begin{array}{l}\text { RISKAN } \\
\text { (Risk calculator } \\
\text { for Managers) }\end{array}$ & $\begin{array}{l}\text { It is used for organization security of govern- } \\
\text { mental and public sector as well as strategic } \\
\text { companies from telecommunications, utility } \\
\text { and financial sectors. }\end{array}$ \\
\hline
\end{tabular}

The aim of this paper is to introduce the product mentioned above that is used for education of students in the Department of Population Protection. It is a methodology for model calculations of the transport and dispersion of pollution in the atmosphere SYMOS'97 (System modeling of stationary sources). This program is also used in the research activities in the field of crisis management and implements its outputs to the process of protecting the environment.

\subsection{Symos'97 Software}

Methodology / SYMOS'97 software allows:

- calculation of air pollution gaseous substances and dust from point, line and area sources,

- calculation of the contamination from a number of sources,

- to identify the characteristics of pollution in dense geometrical network of reference points,

- to consider the statistical distribution of wind speed and direction relative to the stability classes layers of the atmosphere. 
Symos'97 is the tool for quick forecasting of consequences and impacts of chemical materials leaks on the environment (fig. 1). Thanks to this program, it is possible to calculate and visualize the emission leaks and to model the consequences that resulted from contamination of the environment. The model includes connectivity to geographic information system for direct results display in the map. The software can be easily used by non-professionals [3].

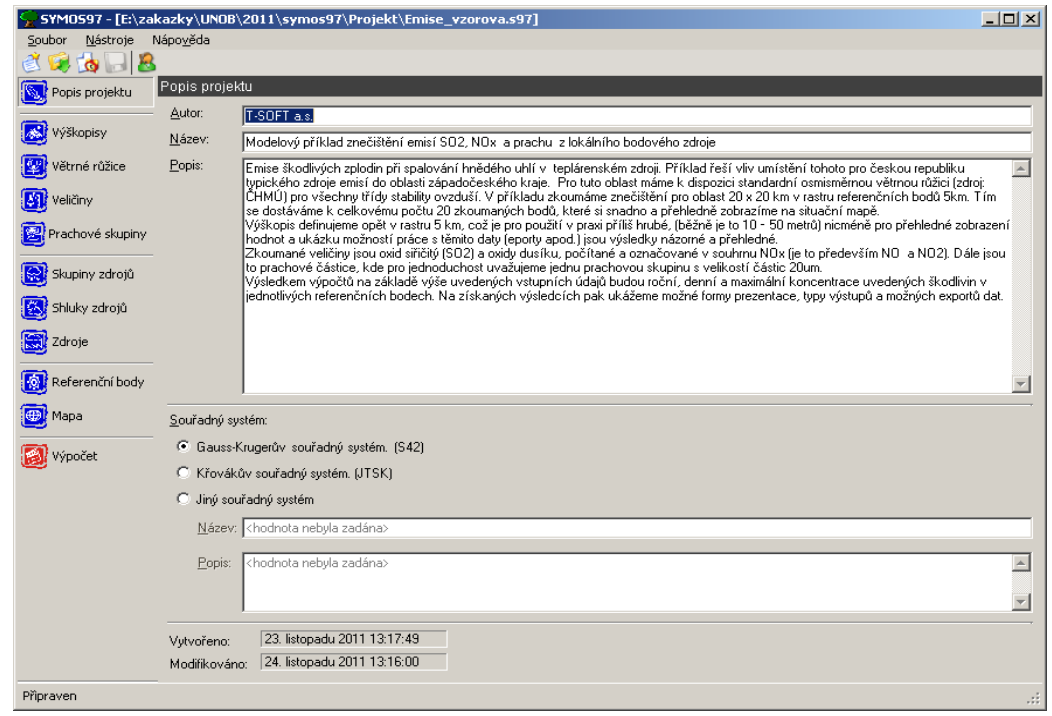

Fig. 1. Symos'97 - start of simulation [2]

Symos'97 calculation results are arranged in a very easy, comprehensive and unambiguous format, which helps to make quick decisions. This effect is achieved by minimizing output items to important ones and by displaying results on the map, as it is in the fig. $2 \& 3$.

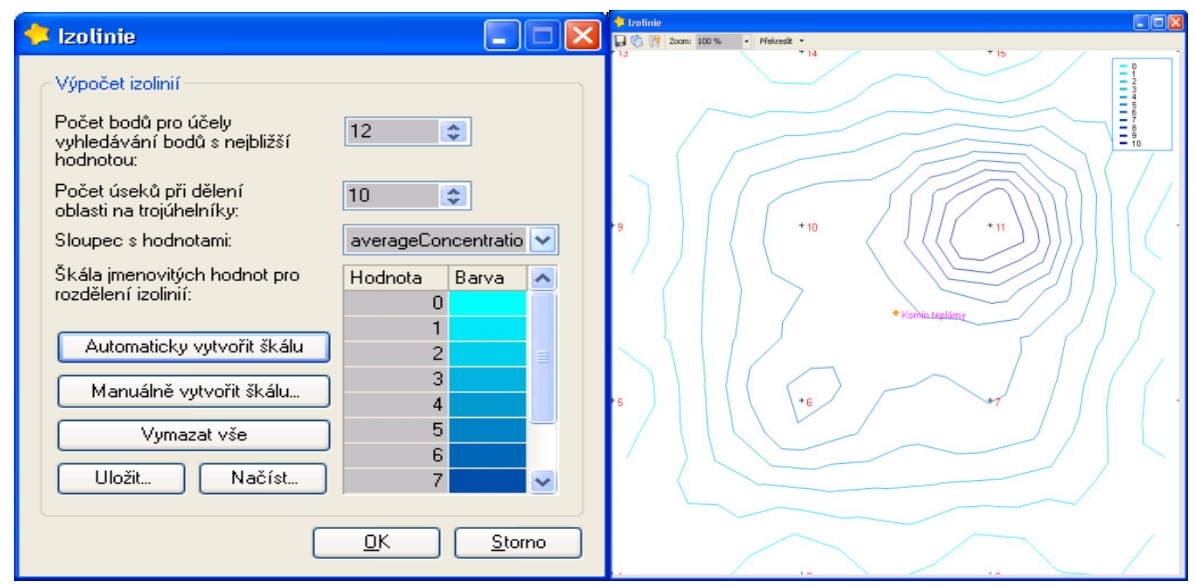

Fig. 2. Concentration and Isolines [2] 


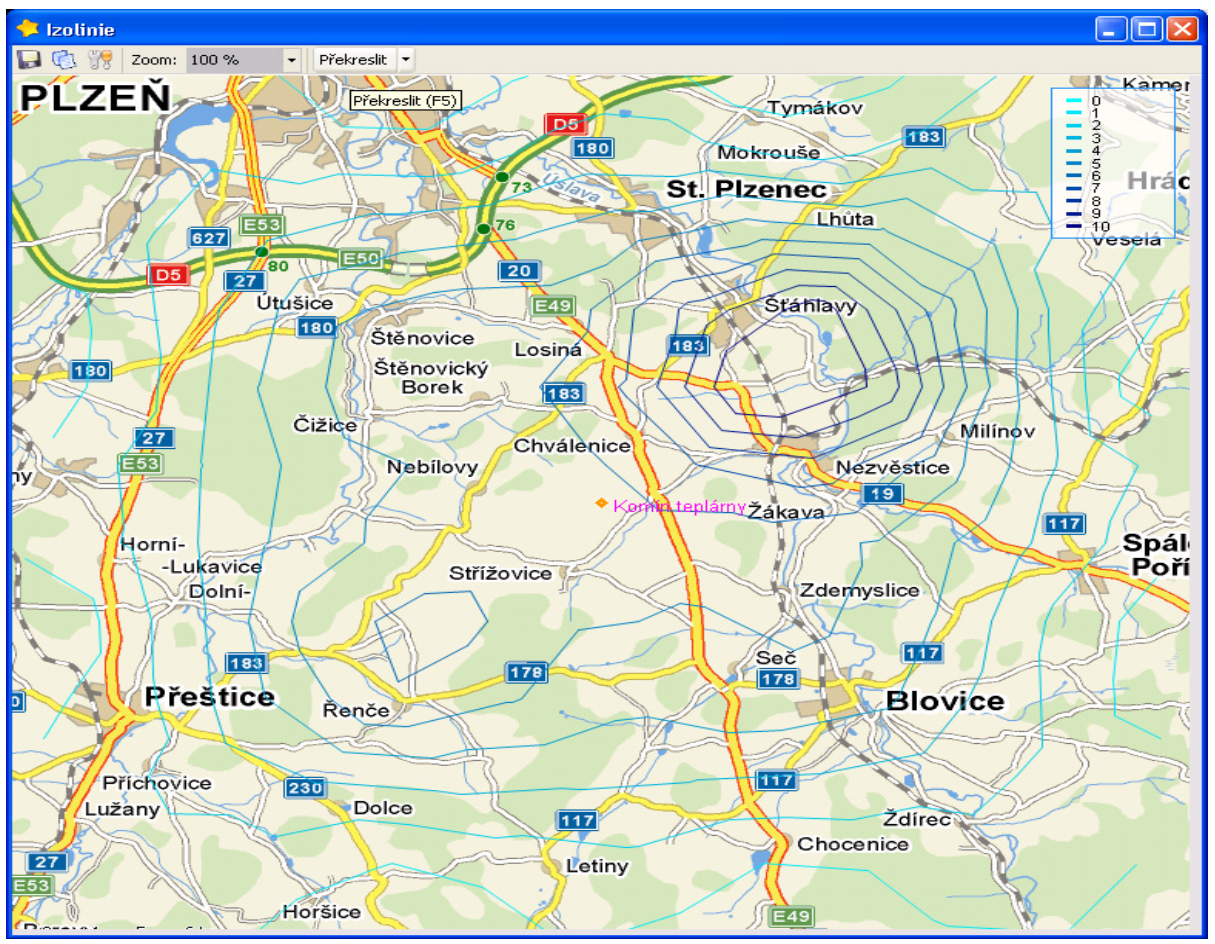

Fig. 3. Isolines on the map [2]

This software is used at distinct projects in terms of its research activities in the field of security, communication, civil-military cooperation and other. One of these projects aims for a novel perspectives and possibilities of "new approaches" to education and training of selected members of management. This research project of the University of Defence is called Interoperability Workplaces to Support Teaching of Security Management in a Computer Network. The primary aim of the research project is to create the new system and technology for education, training and exchange of relevant information with managers of crisis management. The secondary aim of the research project is to use this new system to protect the environment.

To deal with the question of using common security, communication and information technologies and other computer-aided technologies, it is necessary to apply the principle of COTS (Commercial Off The Shelf) as much as possible. That means maximal utilization of commercial products, technologies and services to create a specific system or technology [7].

\section{Specialized Workplaces}

The research project Interoperability Workplaces to Support uses existing structures and systems of communication. The key idea is to connect existing heterogeneous information systems and other relevant organizations in the area of management. 
These individual management entities will be able to exchange information and experiences. They can use selected simulation programs (such as Symos'97) and information systems of other entities connected to the network. Therefore, this will enable the sharing of information and practical experience across the whole spectrum of management and crisis management $[4,6]$.

The system "Workplaces to support teaching of security management in a computer network" is implemented at interface with communication among different systems of crisis management entities. This system can be implemented among expert workplaces, and among the various computers. The system is used in the existing Internet network for communication. Of course, it uses a secure connection via encryption algorithms. The method primarily applies the basic tools for Windows and network settings. The method allows the sharing of computers, the computing space and simulation programs for the education and training of other entities registered in this system [1]. The open system architecture also allows the use of supercomputers in the VSB-Technical University of Ostrava.

\section{$6 \quad$ Testing}

During testing, it is necessary to take into account the fact that throughput communication network is very variable over time. This complicates the stability of information system and the communication between specialized workplaces must be modified to the actual situation. All the results were recorded and the restrictive conditions for using this technology in real situations were defined. The result was a test environment illustrating the real usage of the information and communication system for specialized workplaces.

Developing of a network standard for a facility and connecting interface design is a precondition for building an effective communication expert system, which will satisfy requirements for the needs of management and executive units of crisis management. This system is designed as an open network to which the verification can be accessed by other users of the environment of crisis management and various experts on the issue of terrorist acts, accidents and natural disasters [3].

\section{Conclusion}

Finally, it is necessary to say that all software products represent the function of crisis manager helper in his decision making. All computer programs are only "lifeless" and "thoughtless" products. The crisis manager is principal, especially his knowledge, abilities and acquirements, and many times his extemporization too.

At the same time, it should be noted that this solution is a compromise in many aspects and it does not fully meet needs of all stakeholders. In addition, relations between the lines of preparation for solution of civilian crisis management and lines of preparation and training for crisis management staff have to be considered carefully [6].

The resulting situation can be recognized as an essential qualitative advance, but it has to be developed henceforth. The "Workplace expert of crisis management" 
belongs among the priority issues and it needs to be contemplated from the national security point of view, as well as the crisis management viewpoint.

The first steps to resolve such issues meet consistently all requirements resulting from the Conception of population protection. It is important to detect system uncertainties and gaps, when an issue emerges, and to formulate all requirements on education and training in this area to be further developed.

\section{References}

1. Barta, J.: Project ADAPTIV and its Uses for Protection of the Selected Objects Infrastructure. TRANSACTIONS of the VŠB - Technical University of Ostrava: Safety Engineering Series I, 1-4 (2011)

2. Bubník, J., Keder, J., Macoun, J.: SYMOS 1997, Systém modelování stacionárních zdrojů. Praha (1998)

3. Heretik, J., Barta, J.: Počítačové modelování možných havárií s únikem nebezpečných látek. In: Interoperabilita managementu ochrany obyvatelstva (2006)

4. Ludík, T., Ráček, J.: Process methodology for emergency management. In: Hřebíček, J., Schimak, G., Denzer, R. (eds.) ISESS 2011. IFIP AICT, vol. 359, pp. 302-309. Springer, Heidelberg (2011)

5. Urbánek, J.F., et al.: Scénáře adaptivní kamufláže. Tribun EU, Brno (2012)

6. Urbánek, J.F., et al.: Crisis Scenarios. University of Defence, Brno (2013)

7. Urbánek, J.F., Průcha, J.: A Development of Wireless Interoper-mobile Application for Outdoor Operation Management. In: Proceedings 8th Int. Conf. on Electronics, hardware, wireless and optical communications, EHAC 2009, pp. 57-64. WSEAS Press (2009)

8. Statute of the Faculty Economics and Management. University of Defence. Brno (2005) 